\title{
Appendiceal Carcinoma pT3 TNM Finding v8
}

National Cancer Institute

\section{Source}

National Cancer Institute. Appendiceal Carcinoma pT3 TNM Finding v8. NCI Thesaurus.

Code C134099.

Appendiceal carcinoma with tumor invading through the muscularis propria into the subserosa or the mesoappendix. (from AJCC 8th Ed.) 